\title{
The Metallogenic Setting of Terminal Orogenic Gold Deposits
}

\author{
Norman A. Duke \\ Western Ontario, Canada \\ Email:nduke@uwo.ca
}

How to cite this paper: Duke, N.A. (2021) The Metallogenic Setting of Terminal Orogenic Gold Deposits. Natural Resources, 12 , 348-362.

https://doi.org/10.4236/nr.2021.1210024

Received: September 15, 2021

Accepted: October 24, 2021

Published: October 27, 2021

Copyright (C 2021 by author(s) and Scientific Research Publishing Inc. This work is licensed under the Creative Commons Attribution International License (CC BY 4.0).

http://creativecommons.org/licenses/by/4.0/

Open Access

\section{Introduction: An Essay on Gold Mineralization}

This thought project is focused on the time and place of gold concentration within orogens, the most complex of the tectonic settings resulting from plate interactions. The author has been engaged in gold exploration over his 50-year career and takes this occasion for reflection on "what I think I learned". When overwhelmed by the wealth of immediate field evidence, combined with the mountains of petrographic and geochemical data it is nigh impossible "to see the forest for the trees". All too often reporting of specific "data sets" passes as the goal of science while the real problem, i.e. what all the evidence in combination adds up to, is never engaged. This is an effort to step back and take a larger view of the bigger picture painted by the various roles played by regional and thermal metamorphism, plutonism and volcanism, as well as marine and terrestrial sedimentation within hydrothermal environments of gold concentration.

\section{Plate Tectonic Theory of Orogeny: Plate Convergence, Accretion vs. Collision of Crust, Oceanic Detachment}

The shift from a stable to a dynamic view of the geology of earths' surface in the 1960s has had a profound effect on geotectonic interpretations. Although deceptively simple in concept, that new ocean crust forms at oceanic ridges and is lost in subduction zones, the application of plate theory to decipher the geological history of the crust has proven particularly challenging where the crust is less rigid, as for Archean Shields and especially within the permobile orogenic belts that recur throughout geological time. According to Plate Tectonic Theory, the earths' surface consists of several rigid plates in relative motion to one another. Plate boundaries are divergent at oceanic ridges, convergent at subduction zones or bounded by strike-slip faults known as transforms where plates are simply sliding past one another in the horizontal fashion. As nature is always open to possibility, ridges may be overridden in subduction zones and oblique convergence 
has both the dip-slip and strike-slip components, specific ridge-subductiontransform settings predicted in plate theory are more ideal endmembers than are real settings preserved in the geological record.

In Plate Theory, orogeny is a product of plate convergence, i.e. is driven by the subduction of oceanic plates, but again the simplicity of theory gives way to complexity in practice. When new ocean crust cools as it is conveyed off the axes of global ridge systems it densifies, becomes gravitationally unstable and sinks into the mantle. Initially, this may only involve intra-oceanic subduction, with one oceanic plate underplating another to give rise to primitive island arc settings. Such arcs may be viewed as nascent orogens, but these lack evidence for generating more evolved "continental crust" by way of tectonic recycling. As oceanic plates close, subduction drives arc/arc collisions to form amalgamated arc systems, to eventually drive superarc/continent and continent/continent collisions on full closure. Mature orogens are the result of continent/continent collision and these recur periodically in the geological record, giving rise to the Supercontinents Kenorland, Nuna, Rodinia, Gondwana, and Pangea. The aggregation of Supercontinents in the order of every $500 \mathrm{Ma}$ demonstrates that the history of plate tectonics, the random opening and closing of oceans, drives a higher-order phenomenon, with continental crust dispersing from geoid highs, formed by insulating mantle by the thick continental cover, followed by re-aggregation of continents in geoid lows, formed by the convergence of global subduction zones. Aggregated states of supercontinents are much shorter lived $(<50 \mathrm{Ma})$ than are dispersed states $(>300 \mathrm{Ma})$, as represented by the present global configuration of the continents.

The formation of continental crust through time is a direct result of amalgamating disparate ocean crust, primitive oceanic arc systems, evolved "continental" arc systems as well as pre-formed continental fragments, within collisional orogens that trace convergent plate boundaries globally. Surface trench systems may be choked by clastic sediment, giving rise to accretionary prisms within the array of terranes that construct the overall orogen over the prolonged lifetime of continuous convergence. Significantly, accretionary prisms are not transported but form "insitu", the clastic sediment shed into trenches is too buoyant to subduct into the mantle so builds up thick tectonic wedges within the zone of active subduction. The compressional orogenic environment is maintained so long as subduction of ocean crust continues, however, compression terminates abruptly when the oceanic slab detaches from the more buoyant orogenic root. Left without the driving force for compression, the gravitationally unstable orogen flows latterly under its own weight and collapses in a relatively short period of time (10 - $20 \mathrm{Ma})$. Our interest in the metallogenic setting of gold deposits carries us into this post-compressional stage of orogenic collapse that ensues following slab failure.

\section{Orogenic Evolution}

Orogenic evolution is documented in the history of the Supercontinent Cycles 
making up the geological record. These follow a somewhat regular pattern: 1) Continental dispersal as new oceans form where old oceans closed; 2) Island arc development and arc amalgamation; 3) Arc/continent collision; 4) Continent/ continent collision; 5) Terminal orogenic collapse followed rather quickly by continental dispersal initiating the next cycle. Accordingly, all orogens entail diverse crust of diverse age, they are tapestries of geological complexity. Commensurate with the advancement of Plate Tectonic Theory, Terrane Analysis has developed as a means for deciphering detailed orogenic history. Terrane Analysis involves identifying the type of any given terrane by a coherent structural/stratigraphic framework, and demonstrating how adjoining terranes are related tectonically, i.e. terranes are invariably fault bounded. The essential insight into orogenic evolution afforded by Plate Theory is that suture zones trace sites of ocean closure in past subduction zones. Juxtaposed terranes may have originated $100 \mathrm{~s}$ or even $1000 \mathrm{~s}$ of kilometers apart and haphazardly welded together during prolonged convergence.

Although cold, dense ocean crust capping the aesthenosphere becomes increasingly gravitationally unstable as it transits to eclogite on its passage down subduction zones, arc systems, accretionary prisms and continental fragments remain buoyant, building up a permobile metamorphic/magmatic orogenic infrastructure over the course of convergence. When the dense oceanic slab detaches from the buoyant orogenic root the plate mechanics driving orogenic compression is lost and buoyancy becomes the essential driving force. Rapid orogenic uplift gives rise to high plateaus at the surface while a lateral flow of the non-constrained mobile infrastructure results in extensional collapse of the brittle superstructure. The coincident interplay of buoyant uplift, lateral ductile flow and extensional collapse gives rise to the peaked mountain ranges rimming high plateaus that constructs the physiography of still active orogenic belts such as the Cordilleran and Alpine chains. Importantly, isostatic equilibrium of gravitationally buoyant orogens is rapidly re-established by lateral flow and collapse, rather than slowly through erosion. Tectonic denudation through buoyant uplift combined with lateral flow rapidly exposes the orogenic infrastructure. Deep seated batholiths in high-grade metamorphic terranes are exposed along axes of tectonic thickening by the time isostacy is achieved. Plutons and porphyries intrude low grade metamorphic terranes blanketed by orogenic ashtuff. Relict superstructure is readily stripped by physical erosion, so typically only infrastructural domains are left as evidence from past orogenic events. The relatively rapid termination of orogenic systems is well reflected in the narrow age bracket (10 - 20 $\mathrm{Ma}$ ) demonstrated by geochronological dating of igneous crystallization and metamorphic cooling histories.

Gold mineralization commonly postdates the metamorphic and igneous cooling history by 10 - $20 \mathrm{Ma}$, the post-peak metamorphic concentration of gold signifies the very end of any given orogenic cycle. What is dated is gold-related retrograde hydrothermal alteration (water partitioning into hydrous silicates, metals into the increasingly gaseous fluid phase) overprinting igneous and me- 
tamorphic host rocks along gold-mineralized structural corridors. The primary questions for gold metallogeny entail defining what tectonic framework gives rise to late gold-mineralized structural breaks, why and how these structures become fluidized and what causes gold, a very precious metal $(<5 \mathrm{ppb}$ in any known crustal or mantle reservoir) to concentrate. Certainly, to generate quite local (10 s of cubic kms) gold camps containing $>100 \mathrm{~m} \mathrm{oz}$ gold, voluminous (1000 s of cubic kms) of any crustal and/or mantle reservoir must have been efficiently stripped of gold by an agent that served as a medium for transport into highly focused depositional sites. To unravel this conundrum of coinciding factors one must consider the evolution of a highly specialized hydrothermal fluid within the context of an evolving orogen.

\section{Metallogenic Schemata: Fluid Reservoirs, Transport Mediums, Depositional Sites}

The central problem facing gold metallogeny is considerable diversity in host rock setting, seeing little evidence for any common factors across the spectrum of gold mineralized sites has led many to just conclude "gold is where you find it". At present there is little consensus for any common origin to the lode gold family, genetic camps favouring direct linkages to either hydrous magmas or metamorphic dewatering dominate but remain strongly polarized. Efforts to subdivide deposit types on the base of setting including Mesothermal TAG (Thermal Aureole Gold), Porphyry-related, Shear-hosted, BIF-hosted, Turbidite-hosted; and Epithermal (Volcanic-hosted, Sediment-hosted, Detachmenthosted) has further supported multiple over any single mode of origin. There even remains considerable debate on what respective roles may be played by hypogene (ascending hot) vs. supergene (descending cold) fluid, or indeed by mixing from these separate reservoirs. The primary thesis proffered here is that there is in fact a common origin to the lode gold family, albeit a complex one tied to "orogenic dewatering" accompanying terminal uplift and collapse. Although differing settings involve differing fluid reservoirs and vary considerably in specific host rock/host structure depositional sites, the primary transport medium remains essentially the same, i.e. the active agent for transporting and precipitating gold is a gas-rich aqueous phase liberated during rapid decompression.

Fundamentally, orogens are first order fluid pumps that maintain the stability of the earths' hydrosphere. As new ocean crust forms at oceanic ridges, autohydration of fresh basalt to greenschist facies mineralogy (via spilitization) imports a $5 \%$ to $10 \%$ volatile content derived from seawater. If water was continually lost by subduction of hydrated oceanic crust the hydrosphere would have disappeared over a relatively short period of geological time. Accordingly, as spilitized basalt is prograded to amphibolite then eclogite facies mineralogy on passage down subduction zones its volatile content is expelled. Importantly, as this volatile component is complexed in low-grade mineral assemblages its composition on release is controlled by elemental partitioning between stable high-grade mi- 
neralogy and a fugitive phase. The expelled fluid is dominated by water carrying reduced S-C-Metal species. Chorine, a dominant complex for base metals, remains fixed in stable silicates, and precious metals outcompete base metals in forming reduced S-C species, thereby establishing a specialized fluid lineage for transporting a gold suite (W-Te-Bi-Ag-Au-As-Sb-Hg-Tl). The driving out of reduced precious metal bearing hydrothermal fluid from hydrated ocean crust due to increasing grades of metamorphism supplies the primary reservoir for orogenic gold deposits, although the history separating fluid generation and actual gold concentration may be torturous. Such fluid causes hydration of the slab/mantle interface, giving rise to the serpentinite (Alpine Peridotite) marking sutures, as well as initiates wet melting in the suprasubduction mantle to drive calc-alkaline magmatism, the primary signature of orogens.

The release of fluid from the downgoing oceanic slab is not progressive but tied to metamorphic fronts, the majority ( $5 \mathrm{wt} \%)$ is released at the front of amphibolitization and lesser (3 wt\%) on the conversion to eclogite. The dominant effect is metasomatism of mantle peridotite capping the subduction zone where wet melting gives rise to calc-alkaline magmas. There is a direct relation of calc-alkaline magmatic evolution from primitive Ca-Series, to Na-Series, to K-Series granites with depth on the Benioffe Zone. The common association of gold deposits to late shoshonitic suites (including minette lamprophyres) suggests hydrothermal specialization accompanies magmatic evolution (water partitioning into melt while metals partition into the increasingly volatile fluid phase) and that such evolved gas-rich hydrothermal fluid ponds in domains of melt generation at slab failure. When the oceanic plate decouples from the orogenic root, the depressed mantle wedge capping the subduction zone rebounds before collapse of the overlying buoyant infrastructure, causing mafic (anorthositic gabbro) underplating of the orogen. Wet melting at the base of the orogen gives rise to the bimodal mafic/silicic magmatic association characteristic of extension. Gold mineralization is commonly associated with the silicic ashtuff volcanic fields capped by plateau basalts that blanket orogenic belts. Whereas calc-alkaline magmatism predates orogenic collapse bimodal magmatism coincides with collapse. The ashtuff fields are generally rotated by orogenic extension while capping plateau basalts are not, so these respectively syn- and post-date collapse. The important issue for fluid history is that rapid decompression of the entire orogen following slab failure allows hydrothermal release with the final K-phase of calc-alkaline and the onset of silicic melt generation. Rapid decompression prohibits fluid from dissolving in silicate melt so floods the same conduits as utilized by magmas, i.e. evolved fluid and melts are co-derived. The common associations of gold mineralization to silicic porphyries and minette lamprophyre dykes attest to magma and fluid utilizing the same conduits. Decoupling the direct genesis of fluid from melt, that fluid is sourced in dewatering the failed oceanic slab, solves the volume problem created by linking gold mineralization directly to volumetrically minor igneous injections.

The gold deposits hosted within accretionary complexes represent a different 
metallogenic scheme, these include the Turbidite-Hosted and BIF-Hosted classes. Accretionary complexes buildup over the course of prolonged convergence, the clastic infill is primarily sourced from primitive oceanic arc systems encroaching on trenches. The depositional history predates orogenic uplift, so material from the orogenic interior is not a provenance for trench sediment. Accretionary flysche (marine greywacke-shale) successions are carried down subduction zones into high-grade metamorphic and even melt environments, but these are too buoyant to ride downgoing oceanic plates into mantle. Such clastic wedges supply an even greater water-sulphur-carbon budget than does oceanic crust, and similarly to metamorphic dewatering of oceanic slabs, voluminous reduced fluid is released at the front of amphibolitization of marine sediment. Notably, gold deposits hosted in such terranes generally occur at greenschist/amphibolite transitions. Turbidite-Hosted deposits, such as those in the Maguma Camp, commonly take the form of saddle reefs in fold culminations, suggesting that metamorphic fluid released by amphibolitization simply migrates and ponds in proximal fold fronts. This is also true for such BIF-Hosted deposits as Lupin, only here sulphidization of fold hinges of silicate iron formation provides a chemical trap for greater gold concentration.

\section{Terminal Orogenic Gold Environments: The Brittle/Ductile Transition, Mesothermal and Epithermal Deposits, Hypogene and Supergene Reservoirs, Metal Zoning}

The broad partition into mesothermal and epithermal deposit-types clearly demonstrates that orogenic gold concentration takes place at relatively shallow crustal environments. In active orogens the seismic/aseismic boundary, the ductile to brittle transition, may rise from an average of $12-8 \mathrm{~km}$ to as shallow as 5 $\mathrm{km}$ in domains of extensional thinning. Below this seismic discontinuity, plastic flow accommodates tectonic stress and there are essentially no openings for trapping fluid, high grade metamorphic terranes and deep-seated batholiths are notoriously gold barren. Granulite formed where the base of the orogen is underplated by anorthositic gabbro is the restite left after withdrawal of voluminous silicic fluid/melt giving rise to orogenic ashtuff blankets, as well as the source for liberating the $\mathrm{CO}_{2}$ giving rise to the ubiquitous carbonate flooding of gold mineralized sites at shallower crustal levels. The deepest environment for Mesothermal gold deposits occurs at fronts of amphibolitization, such as the aforementioned Turbidite- and BIF-Hosted examples in accretionary wedges, but also including TAG deposits in the thermal aureoles to plutons within low-grade terranes. Plutons form in the cupolas of batholiths occurring at the ductile to brittle transition and ascend through denser medial crust. Fluids shed from the advancing front of amphibolitization migrate towards the apacie of intrusive columns. The amphibolite hornfelsed aureole forms a far more brittle lithology than bordering greenschists, ongoing buoyancy related to the rise of the pluton generates brittle fracture sets at the outer margin of the aureole, these become 
ductile with fluid ingress resulting in gold mineralized shear zones, i.e. ShearHosted gold deposits, such as the Yellowknife Camp, also occur proximal to greenschist/amphibolite transitions.

Porphyry-related deposits account for most of the world-class gold camps throughout the geological record; the Kirkland Lake, Porcupine and Hemlo camps are exemplary. Commonly, the associated porphyry body is subvolcanic, i.e. intrudes into its own volcanic blanket, so represent epithermal rather than mesothermal depositional environments. However, the mechanics attending orogenic collapse can certainly telescope these crustal conditions. At Hemlo for instance, the Moose Lake Porphyry Complex intrudes a ductile shear within sillimanite-facies metasediment rich in pegmatite melt bodies. The high-grade metamorphic setting notwithstanding, the gold mineralization has related zeolite facies (prehnite-stable) retrograde alteration, i.e. evidence for rapidly coupling subgranulite and subgreenschist metamorphic conditions at the site of porphyry intrusion. The occurrence of molybdenum-bearing pegmatites peripheral to the Pukaskwa Gneiss Dome interior to the gold-molybdenite ore hosted in a monomineralic microcline shear at Hemlo identifies a high temperature hypogene $\mathrm{K}$-metasomatic agent released on collapse. Associated barite signifies inundation by supergene fluid that infiltrated from the paleosurface, as reflected in the preserved lenses of Temiskaming Conglomerate within the mineralized shear zone. The occurrence of post gold mineralization varitextured porphyry dykes in the Hemlo Shear, following a reactivated greenstone/metasedimentary boundary, indicates the transit from ductile to brittle conditions in the waning stages of deformation.

Prime examples of the epithermal class occur in the American Southwest where they were first recognized. These include deep (3 - $5 \mathrm{~km})$ Sediment-Hosted (Carlin Trend), shallow Volcanic-Hosted (Round Mountain) as well as the recently discovered Detachment-Hosted (Picacho) deposits. All these deposits are mid-Tertiary in age, approximately coinciding with the regional effusion of silicic ashtuff (Peach Springs Tuff at 18.5 Ma). Specific ties to silicic volcanic centers indicate gold-bearing hypogene fluid was released through magmatic feeder systems, however, mixing with supergene fluid plays a pivotal role in metal precipitation prompted by redox reactions. Detachment-Hosted deposits reflect extreme extension at the time of mineralization, with the orogenic infrastructure locally denuded prior to ashtuff volcanism. Again, sites of gold precipitation in detachment fault breccias show evidence for mixing hypogene fluid emanating up-dip from feeders of silicic volcanism with supergene fluid migrating down to the plane of detachment from surface. Association of pegmatites with gold mineralization at Picacho and nearby Mesquite deposits reflect the high temperature of the infrastructure at the time of mineralization.

What is too often under-emphasized in models of gold genesis is the fundamental role of sutures in providing conduits for release of orogenic magma and associated gas-charged precious metal-bearing hydrothermal fluid. Sutures represent the trace of subducted oceanic slabs so there is no surprise that fluid 
released by slab dehydration at depth primarily vents back up-dip along the slab/mantle interface into overlying suture zones. The Motherlode Camp is a par-excellent example of gold associated with serpentinite, hydration of mantle peridotite generates buoyant serpentinite that rises in the suture zone. In many cases sutures are not so marked as when traced by "Alpine Peridotite" but are more cryptic, as in the well documented gold mineralized "Structural Breaks" of Archean Shields. These breaks follow boundaries of accretionary wedges, juxtaposing trench sediment against hangingwall greenstone. Dewatering and melt generation from amphibolitized metasediment at depth gives rise to voluminous fluid and associated porphyry injecting reactivated boundary faults. The rather common preservation of molasse-filled (Temiskaming Conglomerate) graben in gold mineralized structural corridors clearly demonstrates these reactivated suture zones were open to surface. The occurrence of both porphyry and gold mineralized clasts in the molasse not only signify that continuing buoyant uplift exposed the gold ores to erosion but clearly demonstrates the gold mineralization predated surface sedimentation, hence such graben infill presents an under-explored environment for placer gold concentration. It is possible that "Temiskaming-type graben" were opened by limited strike-slip transform faulting that accommodated tectonic stress along reactivated sutures at the onset of brittle crustal behavior. Seismic pumping may have played a key role in focusing the most highly evolved fluids into late brittle fault/fracture strands.

Considerable effort has been expended accounting for metal zoning in gold mineralized domains. Typically, mesothermal deposits show only limited or no zoning, although paragenetically, gold precipitation associated with sulphidization (pyritization, pyrhotitization) is succeeded by arsenopyrite growth, indicating increasing arsenic in fluid during cooling. Notably, in the classic ShearHosted Yellowknife Camp, free-milling pyrite-gold ores give way to refractory arsenian-gold ores as the mineralized Con Shears encroach on the Temiskaming-type (Jackson Lake Conglomerate) unconformity. The local concentration of stibnite above refractory arsenian ores in the Giant Shears further identifies marked camp-scale Au-As-Sb partitioning towards the paleosurface. Much more dramatic zoning characterizes the Epithermal Class where there is typical deeper/hotter to shallower/cooler metal partitioning from $\mathrm{Bi} \rightarrow \mathrm{Ag} \rightarrow \mathrm{Au} \rightarrow \mathrm{As} \rightarrow \mathrm{Sb}$ $\rightarrow$ Hg. Consistent with lack of zoning in mesothermal yet marked zoning in epithermal environments is the vertical extent of mineralization, mesothermal shears have km scale extent, while epithermal mineralization is strongly telescoped, occurring only over a $100 \mathrm{~m}$ scale in vertical dimension. Both zoning and vertical extent reflect ambient geothermal conditions, i.e. low vs. high geothermal gradients in respective mesothermal and epithermal environments. In both settings, geothermometry broadly ties gold precipitation to the $400^{\circ} \mathrm{C}$ to $200^{\circ} \mathrm{C}$ cooling history of the transporting agent. While there is little or no evidence for boiling or hypogene/supergene fluid mixing in mesothermal ores, these are the norm in epithermal ores, again reflecting proximity to a paleosurface. Where well preserved, such as in the still active central Taupo Graben of New Zealand, 
there is considerable evidence that epithermal deposits are originally capped by surface hotsprings. The silica sinter precipitated at surface overlies advanced argillic alteration developed where gases released by boiling causes intense acid base leaching at the water table.

\section{Gold Events in the Geological Record: The Collapse of Collisional Orogens through Time}

1) The Mesoarchean Witwatersrand Gold Event

Vestiges of $4 \mathrm{Ga}$ crust are widely distributed but make up a relatively minor component of Earths cratons, the Kaapvaal Shield of South Africa is the best representative. Its greenstone assemblages are rich in komatiite members, identifying abnormally hot geothermal conditions relic from core formation and high partial melting of the mantle. The Zimbabwe Shield is somewhat similar in its makeup to the Kaapvaal and these are separated by the Limpopo Metamorphic Belt, exposing deep crustal granulite gneiss intruded by anorthosite. The Limpopo originated as an infrastructural accretionary complex during collision of the Kaapvaal and Zimbabwe cratonic nuclei, detachment of sagducted oceanic crust resulting in buoyant rise from the crust/mantle boundary between 3.8 and 3.6 Ga.

The Witwatersrand Basin is the largest known single depository for gold globally, it unconformably overlies the northern margin of the Kaapvaal south of the Limpopo. A series of Hydrothermally Altered Granite stocks (HAGs) exposed along the northern margin of the Witwatersrand sediments signifies that high level mesothermal/epithermal gold environments developed in the Kaapvaal lid capping the Limpopo. Such settings were exposed to subaerial erosion by braided river systems draining southward and forming prograding delta fans into deepening marine conditions within the Witwatersrand Basin. Placer gold is concentrated in multiple lag vein quartz-pyrite pebble conglomerate horizons, associated black shale/iron formation units in the gold mineralized stratigraphy reflect numerous transgressive/regressive cycles of the marine shoreline. Moderate secondary remobilization of the placer gold due to post depositional hydrothermal activity resulted in gold enrichment of the intervening black shale/ iron formation units.

2) The Neoarchean Kenoran Gold Event

The 2.7 - $2.5 \mathrm{Ga}$ Kenoran Orogeny gave rise to the greatest granite bloom in Earth History and resulted in stablizing the classic granite/greenstone and granite/metasediment terranes that characterize Neoarchean Shields globally. The "room problem" for the diapiric emplacement of plutons is resolved by gravitational foundering of the superstructure, vertical extensional collapse results in plutons bordered by amphibolite facies thermal aureoles overprinting steeply dipping greenstone successions that young away from plutonic centers. Collectively, these terranes host the great majority of the Earths Gold Camps and have supplied much of the historic gold production. Certainly, the primitive "oceanic cratons" that formed in the Archean are the most endowed with gold deposits, 
the Superior and Slave provinces are representative and well known for hosting world class gold camps. The Kenoran granites intruded between 2.7 and $2.6 \mathrm{Ga}$ in the Superior and between 2.6 and $2.5 \mathrm{Ga}$ in the Slave, demonstrating a somewhat diachronous orogenic history within the aggregated landmass of Kenorland.

The Neoarchean greenstone assemblages represent amalgamated primitive oceanic arc systems while the metasedimentary assemblages represent accretionary wedges that developed over the course of prolonged convergence driven by oceanic sagduction. Upon oceanic detachment both were flooded by granite plutons, suggesting a largely molten orogenic infrastructure, I-type granites are generated in greenstone terranes, S-type granites within metasedimentary terranes. Gold mineralization accompanies the diapiric rise of granites and focusses on Structural Breaks following greenstone/metasediment boundaries. These boundaries have a very long history, originating as oceanic sutures that were reactivated by bouyancy following oceanic detachment and terminating with limited strike-slip displacement. They were open to the surface, giving rise to the deposition of fault-controlled Temiskaming-type orogenic conglomerates. At depth, gold is concentrated in shear zones at the outer margin of thermal aureoles to high level plutons, becoming more widespread within shallower porphyry settings. Continuing uplift due to the buoyant rise of plutons exposed the epithermal/mesothermal gold concentrations to physical erosion during deposition of the Temiskaming conglomerates.

3) The Paleoproterozoic Hudsonian Gold Event

The Paleoproterozoic shields of Nuna are characterized by collapsed "dome and keel" metamorphic terranes wherein considerable Archean crust is recycled, the Churchill Province and broadly analogous Amazon Craton are representative. In the Churchill the $1900 \mathrm{Ma}$ arc systems of the Flin Flon-Lynn Lake-Snow Lake terranes were amalgamated during the TransHudson Orogenic Cycle, culminating in the $1850 \mathrm{Ma}$ Wathaman Batholith and widespread Hudsonian I-type granite plutons. Post orogenic A-type granite plutonism gave rise to the $1750 \mathrm{Ma}$ Nuelton Suite. The Hudsonian regional metamorphic overprint of Neoarchean basement varies from mild, such as in the Kaminak granite/greenstone terrane of the Hearne Domain to intense, such as in the accretionary Committee Bay terrane of the Rae Domain. The gold deposits in the Kaminak and Committee Bay belts are Archean in age and overprinted by Hudsonian metamorphism. Erosion of Archean mineralization resulted in placer gold concentrations within the unconformably overlying Paleoproterozoic Hurwitz Supergroup. There are also prime examples of Paleoproterozoic-age lode gold camps, such as the La Ronge Gold Belt, with gold concentrating in sheared Hudsonian granite where intruded by lamprophyre dykes, and in the Agassis Metallotect with gold mineralized iron formation occurring along a reactivated accretionary boundary. There are reports of IOCG-type mineralization associated with the intrusion of the A-Type Nuelton granites. 
In the Paleoproterozoic Great Bear Province, the amalgamated Hottah Arc obducted the western Slave Supergroup giving rise to the Wopmay Orogen. The $4 \mathrm{Ga}$ Accasta Gneisses in the Wopmay foreland are preserved vestiges of Mesoarchean basement separating the Hottah Arc and Slave Craton. The Wopmay gave rise to the 1900 Ma I-type Hepburn Plutonic Suite. The central Great Bear Magmatic Zone exposes an 1865 Ma granite batholith capped by orogenic ashtuff of the same age, signifying rapid denudation of the Wopmay infrastructure. Post collisional A-type rapakivi granite plutons intruded at $1850 \mathrm{Ma}$ and these have associated IOCG-type mineralization. The IOCG Sue Dianne Deposit is hosted in basal ashtuffs overlying porphyry, identifying a late intrusive center. At the IOCG NICO Deposit, K-Fe metasomatism related to polymetallic Co-Bi-Au-As-U mineralization is linked to porphyry dykes of rapakivi age injecting the accretionary metasediments of the Treasure Island Group bordering on the GBMZ. The apparent lack of mesothermal/epithermal gold deposits in the Bear may be due to under-exploration in this remote part of the Canadian Shield. Mesothermal mineralization might be expected to be associated with the Hepburn plutons and epithermal mineralization might be hosted in the orogenic ashtuff capping the GBMZ.

4) The Mesoproterozoic Grenvillian Gold Event

The Grenville Province is the best preserved and studied segment of the Grenville collisional orogen that resulted in the aggregation of Rodinia, other vestiges appear in the Precordillera of Argentina, the Albany Fraser Belt of southwest Australia and in the Namaqualand Belt of southern Africa. In eastern Canada the northeast-trending, shallow southeast-dipping Grenville Front traces the leading edge of the Grenville metamorphic overprint of the adjacent east-west trending Neoarchean and Paleoproterozoic crustal elements. The Allocthonous Boundary Thrust (ABT) interior to the Grenville Front separates parathochthonous Archean and Paleoproterozoic gneisses from allochthonous crust exotic to Laurentia that docked during prolonged Grenville collision. Relict eclogite at the base of the ABT signifies an exhumed paleosubduction zone, Mesoproterozoic oceanic crust that formed outboard of Laurentia was subducted below Grenvillian elements. The overlying northeastern Central Gneiss Belt is largely Mesoproterozoic arc elements severely reworked during the high grade Grenvillian metamorphic overprint. The southeastern Central Granulite Belt is similarly aged arc elements heavily intruded by Grenvillian anorthosite. The Amazon Craton formed an outboard continental landmass that collided with Laurentia, giving rise to this major continent/continent collisional segment of the orogen. The only low grade supracrustal elements are confined to the Central Metasedimentary Belt, floored by $1300 \mathrm{Ma}$ Tudor Volcanics, which is overlain by the Grenville Supergroup dominated by dolomite. Extensional shears bounding the $\mathrm{CMB}$ accommodated the collapse of this shallow marine inter-arc basin, bordering deep crustal granulite gneisses intruded by 1160 - $1140 \mathrm{Ma}$ anorthosite attest to rapid buoyant rise of the underlying orogenic infrastructure. 
Grenvillian gold deposits are restricted to the juvenile Central Metasedimentary Belt, the first gold mineralization discovered in Canada were prospects in the Kaladar-Madoc area of the Elsevere Terrane. The Kaladar Complex may be a metamorphosed fragment of obducted seafloor. This portion of the Central Metasedimentary Belt was intruded by the $1180 \mathrm{Ma}$ Elseverian granites prior to the final Grenville collision at $1 \mathrm{Ga}$. Within the immediate area of the gold prospects the Grenville Supergroup is unconformably overlain by the Flinton Group, its basal conglomerate member, the Ore Chimney Formation, postdates the intrusion of Elseverian granites but predates the final Grenville collision. Many of the gold prospects are hosted by sheared aluminous Ore Chimney Schist developed at the Flinton Group unconformity and in underlying dolomite. Primary gold concentration relates to detachment of the Elseverian oceanic plate, thus predates final continent/continent collision and its attendant regional Grenville metamorphic overprint.

5) The Neoproterozoic Panafrican Gold Event

By the Neoproterozoic, the Earth had cooled to the point of demonstrating rigid plate tectonics analogous to present day. The Panafrican Cycle results in dispersal of Rodinia, the breakout of Laurentia from its core turned Rodinia inside out and closure of the external Panthalasic Ocean results in the aggregation of Gondwana. As its name implies, Panafrican orogenic systems are best represented on the African continent. Opening and closure of interior seas occurred during the 950 - 750 Ma Katanga Cycle, opening and closing of the Adamaster Ocean between Africa and South America occurred during the 750 - 550 Ma Damaran Cycle. Panafrican elements include the first appearance of true ophiolite sequences signifying seafloor spreading and blue schist terranes emblematic of paleosubduction zones. Panafrican Arcs include Cadomia of Wales, Avalonia of the northern and Penobscot of the southern Appalachians and the Brasiliano of Brazil. High pressure elements occur in the eastern Mozambique Belt of Africa and within its continuation on the northwest margin of Antarctica. Arabia is largely underlain by amalgamated primitive oceanic arc systems, forming an "arc graveyard", and obducted Panafrican ophiolites border on the Red Sea. The earliest historical mining of gold was carried out by the Romans in Egypt in the region of the Meatic Domes. Here Metamorphic Core Complexes (MCCs) updome overlying ophiolite, well developed detachment faults separating high grade metamorphic domes from overlying low-grade ophiolite sequences attest to lateral ductile flow in the Panafrican orogenic infrastructure and extensional collapse of the ophiolitic superstructure. The gold is concentrated in brittle/ductile shears accommodating displacement above the zone of detachment. Numerous gold deposits are associated with orogenic felsic porphyry centers within the Panafrican arc systems that occur along the length of the Appalachians and by terminal Panafrican shears within the Brasiliano.

6) The Paleozoic Hercynian Gold Event

The breakup of Gondwana by interior seas opening between Eastern Gondwana (India-Australia-Antarctica) and Western Gondwana (Africa-South America) 
began in the Cambrian by $550 \mathrm{Ma}$. The Iapatus Ocean separated Laurentia from Baltica and Panafrican arcs formed on the western margin of Africa, the Rheic Ocean separated these Panafrican arcs and Baltica from Africa. Pangea was formed by closing these interior oceans. Iapetus ophiolites and juvenile arcs were obducted onto the seaboards of Laurentia/Baltica during the $450 \mathrm{Ma}$ Taconic/Caledonian Orogeny. The Iapetus Ocean closed with docking of Panafrican arcs in the mid-Devonian, giving rise to the $350 \mathrm{Ma}$ Acadian Orogeny. Final closure of the Rheic Ocean resulted in Laurentia and Baltica aggregating with Gondwana in the Mississippian to form Pangea, continent/continent collision gives rise to the $300 \mathrm{Ma}$ Hercynian Granites of Eurasia and the Alleghenian Granites in Appalachia. The most notable gold camp of this age is the Muruntau District of Uzbekistan occurring within a domal accretionary complex, the uplift during intrusion of Hercynian granites drove a switch from marine to terrestrial sedimentation. The Alleghenian Meguma District in Nova Scotia is another notable camp with gold hosted in upper Paleozoic flysche at the front of amphibolite facies metamorphism.

7) The Mid-Tertiary Laramide Gold Event

The western margin of Laurentia remained active following the aggregation of Pangea, docking of arcs in the Mississippian gave rise to the Cordilleran Antler disturbance due to arc/continent collisions. The Roberts Mountain Thrust in Nevada superposed a hot Devonian oceanic plate over continental margin black shales of similar age, activated carbon at the base of the thrust becomes an important chemical trap for later mid-Tertiary epithermal gold concentration in the Carlin District. The RMT reappears as the Slide Mountain Allochthons in the northern Cordillera where obducted Mississippian ophiolites overly the Laramide metamorphic infrastructure in the Klondike District. The Triassic Foothills Suture is the site of the Motherlode Gold District in California, with gold concentrated proximal to serpentinite injecting the accretionary Mariposa Slates. Opening-up of the Atlantic beginning in the Triassic at $250 \mathrm{Ma}$ caused Laurentia to drift westward and the rising Cordillera overrode bordering young Pacific Ocean crust. Underplating the rising Cordilleran with a hot oceanic plate gave rise to the Laramide Orogeny, famous for its prolific 90 - 60 Ma porphyry copper and 30 - 15 Ma mid-Tertiary epithermal gold deposits. The epithermal deposits are Eocene in age north of the Snake River Plain but Miocene in age to the south, demonstrating a diachronous docking history due to tectonic complexity in the Laramide oceanic plate. The Snake River flood basalts track the path of the Yellowstone Plume. The epithermal gold province in the SWUS is the largest gold producing district outside of the Witwatersrand. These deposits relate to post-collisional collapse of the Laramide Orogen, driven by east to west delamination of the oceanic plate. The more prolific Miocene deposits south of the Snake River basalts approximate the Peach Springs Ashflow Tuff Event at 18.5 Ma. Remnants of Peach Spring Tuff have been traced across the Laramide Orogen from the Rio Grande Rift to the San Andreas Fault. The epithermal gold settings center on multiple caulderas that collapsed above the laterally extending 
Laramide infrastructure.

\section{Conclusions: Interpolating Geological Evidence, Multiple Factors/Unique Solutions, Unknowns}

The goal of metallogeny is to understand the genesis of metallic ore deposits in order to discover more. If ore concentration can be tied to specific geological environments then the first order task for exploration is to identify similar settings in the geological record, i.e. "to successfully find elephants one must first be in elephant country." The primary challenge is to rightly interpret the geological evidence at hand. The shift from a stabilist to a mobilist perspective infinitely problematizes the task of interpretation by recognizing that geological evidence is itself a product of far-field crustal processes operative on a global scale. Modern Plate Tectonic Theory supplies this global framework that underpins the history of rock formation throughout the geological record.

Specific sites of ore concentration are defined by the coincidence of multiple processes tying metal reservoirs to transport agents to depositional traps. As a result, all ore deposits are somewhat unique. In the case of gold deposits, this chain of coincidence must upgrade gold concentrations from less than $5 \mathrm{ppb}$ in any known crustal or mantle reservoir to an economically minable content of 1 $10 \mathrm{ppm}$, i.e. a concentration factor over 10,000×. This amazing enrichment demonstrated at gold camps broadly accounts for the "precious metal" designation. Our application of plate theory to deciphering the geological record is still in its infancy, particularly in the less ridged crustal conditions that prevailed in the Archean. Nevertheless, in this review of collisional orogenic systems through time, it is clear some form of modified plate tectonics has been operative since the beginning of crust formation at $4 \mathrm{Ga}$. Also, the case is made that the processes of gold concentration are fundamentally tied to detachment of oceanic lithosphere and the dehydration of the oceanic plate as it sinks into the mantle. The rather common occurrence of obducted ophiolites capping domal orogenic infrastructure in gold districts clearly demonstrates a direct link to lost oceanic crust. The released fluid plays a pivotal role in the development of overlying orogens by forming wet calc-alkaline melts, the co-evolving gas-charged hydrothermal fluid stays mobile until captured in terminal orogenic brittle/ductile deformation zones occurring above the zone of detachment.

Our understanding is severely curtailed by poorly deciphered metallogenic processes and outright unknowns, "by the devils in the details". Little is known about metal partitioning in the high-pressure environment of oceanic subduction, invoked here as the primary reservoir for the gold transporting agent. Even less is known about how such fluids specialize over the course of mantle hydration in the production of serpentinite or in wet melting to produce calc-alkaline magmas. Specific ties to shoshonitic suites strongly suggest that more gascharged metal-enriched fluid is produced at depth, perhaps at the conversion to eclogite. Oceanic detachment from the buoyant orogenic root is undoubtedly key for fluid release, much of which ponds at the base of the orogen to initiate 
the production of voluminous silicic melt giving rise to orogenic ashtuff fields. Very little is known about fluid/melt partitioning during rapid decompression accompanying orogenic collapse. Certainly, rapid depressurization favours production of dryer melt and more voluminous hydrothermal fluid. Pathways for fluid migration from its source to ponding above the ductile orogenic infrastructure are closely tied to magmatic conduits-with the exception of deposits hosted in accretionary complexes devoid of any igneous association. Furthermore, when the orogenic infrastructure is rapidly unroofed, it is locally exposed at the surface prior to silicic volcanism, downward migrating surface water may interact with hot amphibolite facies metamorphic rocks so its supergene signature may be compromised by rock-dominated reactions, becoming in effect more metamorphic in its chemical signature. The specific roles played by highly specialized hypogene and supergene fluid regimes remain obscure at many epithermal deposits, particularly those sited on detachment faults. Tracing the lineage of highly specialized gas-charged hydrothermal fluids is a unique challenge facing gold metallogeny.

\section{Acknowledgements}

This essay on gold mineralization draws from several common research themes, its primary contribution is offering a unified explanation for global gold metallotects. Posing more answers than questions it risks numerous errors of interpretation. I have had the great privilege of carrying on the rich tradition of field-based Economic Geology in the Earth Sciences Department at the University of Western Ontario, following in the footsteps of Gord Suffel, Dick Hutchinson and Bob Hodder. It is dedicated to my longtime mentor and colleague W. R. Church whose encyclopedic knowledge of global tectonics and the related fields of metamorphic, igneous and sedimentary petrology remains an inspiration. The author invites comments or questions at nduke@uwo.ca.

\section{Conflicts of Interest}

The author declares no conflicts of interest regarding the publication of this paper. 